\title{
Follicular Dynamic and Repeatability of Follicular Wave Development in Peranakan Ongole (PO) Cattle
}

\author{
Imron $\mathrm{M}^{1}$, Supriatna $\mathrm{I}^{2}$, Amrozi ${ }^{2}$, Setiadi $\mathrm{MA}^{2}$ \\ ${ }^{1}$ Livestock Embryo Center, Cipelang, Bogor PO Box 485 Bogor 16004 \\ ${ }^{2}$ Division of Reproduction and Toxicology, Department of Pathology and Reproduction Clinic, Faculty of Veterinary, Bogor Agricultural \\ University, Jl. Agatis, Kampus IPB Dramaga-Bogor 16680 \\ E-mail: hibbanie@gmail.com
}

(received 11-01-2016; revised 29-02-2016; accepted 07-03-2016)

\begin{abstract}
ABSTRAK
Imron M, Supriatna I, Amrozi, Setiadi MA. 2016. Dinamika folikel dan repeatabilitas pertumbuhan gelombang folikel pada sapi peranakan ongole (PO). JITV 21(1): 26-33. DOI: http://dx.doi.org/10.14334/jitv.v21i1.1349

Perlakuan superovulasi pada sapi PO (Bos indicus) memiliki respon yang rendah dibandingkan dengan rumpun Bos taurus yang mungkin berhubungan dengan perbedaan dinamika folikel antara kedua rumpun sapi. Penelitian ini dilakukan untuk mengetahui dinamika folikel dan repeatabilitas pola pertumbuhan gelombang folikel pada sapi PO. Pada tahap awal, penelitian menggunakan 9 ekor sapi PO berumur 5-7 tahun. Pengamatan dilakukan dengan menggunakan ultrasonografi (USG) setiap hari. Hasil pengamatan menunjukkan sapi PO memiliki pola $3(66 \%)$ dan $4(34 \%)$ gelombang pertumbuhan folikel dalam satu siklus. Gelombang folikel pertama dari pola gelombang 3 dan 4 terlihat berturut-turut hari ke $0,4 \pm 0,9$ dan $1,4 \pm 1,1$ relatif terhadap terjadinya ovulasi. Gelombang kedua terjadi berturut-turut hari ke $9,8 \pm 1,5$ dan 7,4 41,9 pada pola 3 dan 4 gelombang, relatif terhadap terjadinya ovulasi. Pola 3 gelombang memiliki durasi folikel dominan lebih panjang $(11,6 \pm 1,5$ hari) dibandingkan pola 4 gelombang (10 $\pm 2,9$ hari). Kecepatan pertumbuhan folikel dominan tidak berbeda antara pola 3 dan 4 gelombang folikel $(0,87 \pm 0,23$ dan $0,94 \pm 0.25 \mathrm{~mm} / \mathrm{hari})$. Diameter folikel ovulatori antara pola 3 dan 4 gelombang folikel tidak berbeda yaitu berturut-turut 12,24 $\pm 0,71$ dan 12,30 $\pm 0,22 \mathrm{~mm}$. Diameter CL juga tidak berbeda antara pola 3 dan 4 gelombang folikel, yaitu $18,94 \pm 0,47$ dan 19,44 $\pm 0,87 \mathrm{~mm}$. Pengamatan repeatabilitas pola gelombang yang dilakukan menggunakan 6 ekor menunjukkan sapi PO memiliki repeatabilitas tinggi pada pola gelombang $(0,88)$ dan jumlah folikel yang berkembang $(0,91)$. Penelitian ini menunjukkan data dinamika perkembangan folikel, pola gelombang dan repeatabilitasnya yang diharapkan membantu mendesain protokol perlakuan superovulasi atau teknologi reproduksi yang lain berbasis dinamika folikel sapi PO agar memperoleh respon yang lebih baik.
\end{abstract}

Kata Kunci: Sapi PO, Gelombang Folikel, Repeatabilitas, Interovulatori Interval

\begin{abstract}
Imron M, Supriatna I, Amrozi, Setiadi MA. 2016. Follicular dynamic and repeatability of follicular wave development in Peranakan Ongole (PO) cattle. JITV 21(1): 26-33. DOI: http://dx.doi.org/10.14334/jitv.v21i1.1349

Superovulation treatment on PO cattle (Bos indicus) was less responsive compared to Bos taurus breed. It might due to the difference of their follicular dynamic. This study was conducted to investigate the follicular dynamics and its repeatability in PO cattle. Follicular dynamics observations conducted on 9 cows trough ultrasound scanning every day. Observations of wave patterns repeatability were performed in 6 cows which its wave pattern already known on the next consecutive IOI. Research result indicated that PO cattle had $3(66 \%)$ and 4-waves (34\%) pattern. The first wave of 3 and 4-waves pattern emerged on day $0.4+0.9$ and 1.4+1.1 respectively. The second wave of 3 and 4-wave pattern emerged on day $9.8+1.5$ and $7.4+1.9$ respectively. The pattern of 3 waves has a longer follicle dominant duration (11.6+1.5 day) in the first wave of estrous cycle, compared with 4 waves pattern $(10+2.92$ and $7+1.00$ day respectively). The growth rate of dominant follicle was not different significantly between the 3 and 4 -waves pattern $(0.87+0.23$ and $0.94+0.25 \mathrm{~mm} /$ day respectively). Similarly, ovulatory follicle diameter between 3 and 4-waves pattern was also not different significantly $(12.24+12.34$ and $12.30+12.23$ mm respectively). Observation of wave patterns repeatability in $6 \mathrm{PO}$ cows indicated that PO cattle had high repeatability in follicular wave pattern $(0.88)$ and the number of growing follicle was 0.91 . This study resulted data for dynamic of follicular development, wave pattern, its repeatability which be expected to design the protocol of superovulation treatment or other reproduction technologies based on follicular dynamic to improve its result in PO cattle.
\end{abstract}

Key Words: PO Cattle, Follicular Wave, Repeatability, Interovulatory Interval 


\section{INTRODUCTION}

Follicular wave was identified by growth of a small group follicle with diameter by 3-4 $\mathrm{mm}$ (Taylor \& Rajamahendran 1991). Wave growth pattern of follicle might be observed in prepubertal (Melvin et al. 1999), during pregnancy (lactating period) (Taylor \& Rajamahendran 1991), post-partum (Murphy et al. 1990), and during estrus cycle (Roche et al. 1999). Growth of follicular wave was began with increase of concentration of FSH serum and followed by sudden growth of 8-41 small follicles in 2-3 days (Ginther et al. 1997). One follicle would be selected to continuously grow to be dominant follicle (DF), meanwhile the smaller follicles would be subordinate follicle (SF) and would undergo an atresia. If there was a luteolysis in the growing-phase DF, follicle would undergo final maturation process continued by ovulation. If there was no lutheolysis in the growing DF, the DF would undergo an atresia (Vasenna et al. 2003; Jaiswal et al. 2004; Adam et al. 2008).

Most of cattle breed showed 2 and 3 follicular wave pattern in one estrous cycle (Adam et al. 2008) although sometimes showed 1, 4, and 5 follicular wave pattern (Bleach et al. 2004; Viana et al. 2000). Follicular dynamic was one of research subjects which have been much studied in Europe breed (Bos taurus) but information of zebu cattle (Bos indicus) was very limited. Bó et al. (2003) has reviewed that reproduction characteristic of $B$. indicus cattle was different from $B$. taurus such as in length of estrous cycle, estrous time, estrous behavior, growth of dominant follicle and CL.

Superovulation program at Cipelang Livestock Embryo Center (LET) performed to PO cattle (Bos indicus) as donor showed lower ration of transferable embryo per total embryo collected (1.5 embryos) than Angus, Simmental and Limousine cattle (Bos taurus) which had ratio by $4.75,3.37$ and 2.96 embryos respectively (BET 2012). Hormone injection in superovulation was undifferentiated between donor from Bos taurus (Simmental and Limousine cattle) and donor from Bos indicus (PO cattle). Bó \& Mapletoft (2014) said that response of superovulation would be optimal if follicle super-stimulation treatment was started in the beginning of follicular growth wave emergence. One day earlier or later gonadotropin treatment from initial follicular wave would decrease superovulation response compared to starting treatment right at the time of the initial follicular wave emergence (Bó et al. 2008). It was assumed that there was a relation of difference of reproduction characteristic between both cattle breeds especially in follicular wave pattern with the obstacles faced in superovulation program in PO cattle. Information of characteristic of ovulary dynamic and its repeatability are needed to optimize superovulation program in PO cattle.
This study was conducted to determine characteristic of ovulary dynamic during estrous cycle and repeatability rate of follicular growth wave pattern in Peranakan Ongole (PO) cattle.

\section{MATERIALS AND METHODS}

\section{Materials}

In this study 9 five-seven years old PO cows with body weight of $375-450 \mathrm{~kg}$ were used. All cows had Body Condition Value (BCV) ranged in 2.7-3.2 of scale 1-5 with normal estrous cycle. Diet was provided as 30$40 \mathrm{~kg}$ of grass per head per day and $2-3 \mathrm{~kg}$ of commercial diet per head per day.

\section{Ovulation synchronization}

This study was started by ovulation synchronization to synchronize initial observation of ovulary dynamic through installation of intra-vaginal progesterone preparate $\quad\left(\right.$ Cuemate $^{\circledR}$, consisted of $1.56 \mathrm{mg}$ progesterone in 2 pod silicon, Bioniche Animal Health (A/Asia) Pty.Ltd., Australia) followed by injection of $100 \mu \mathrm{g}$ GnRH (Fertagyl $^{\circledR}$, Intervet Schering-Plough Animal Health, German) in the first day. Cuemate ${ }^{\circledR}$ was entered into vagina for 7 days using special applicator oiled by isotonic gel. PGF $2 \alpha$ (Prostavet $^{\circledR}$ C, $5 \mathrm{mg}$ of etiprostone per $2 \mathrm{ml}$ of solution; Virbac Animal Health, France) was injected intramuscularly along with Cuemate $^{\circledR}$ releasing in vagina. Two days later, $100 \mu \mathrm{g}$ GnRH (Fertagyl ${ }^{\circledR}$, Intervet Schering-Plough Animal Health, German) was added intramuscularly to induce ovulation synchronization.

\section{Observation of follicular dynamic}

Observation of follicular dynamic was performed once a day at the same time and operator using portable ultrasonic (EasyScan Lite, England) equipped with goggle monitor and probe with dynamic frequency by 4-8 Mhz. The main unit of ultrasound was connected to computer and data were recorded in video version. Measurement of diameter of follicle was conducted using Microsoft image tool. Daily observation using ultrasound was started when PO cattle injected by PGF2 $\alpha$. One inter-ovulatory interval (IOI) was defined as time period between 1 ovulation with the next ovulation. First ovulation observed after ovulation synchronization was assumed as day-0 in 1 IOI.

In the initial step, observation was conducted to obtain characteristic of follicular dynamic and for wave pattern in 1 IOI mapping. Nine cows were used in the initial study. To obtain repeatability of follicular wave growth, observation of follicular dynamic was continued in the next1 IOI without a break using 6 cows 
( 3 cows with 3 -wave pattern and 3 cows with 4-wave pattern).

\section{Data analysis}

One follicular wave was defined as duration of follicular growth started from $4 \mathrm{~mm}$ diameter until the dominant follicle back to its original size. Follicle reaching the biggest size from the same wave was stated as dominant follicle (DF), meanwhile smaller follicle was defined as subordinate follicle (SF). Follicular growth phase was a period of follicle detected in $4 \mathrm{~mm}$ of diameter until the time the follicle did not grow anymore. Regression phase was started at the time follicle diameter decreased until getting hard to be detected individually. Static phase was defined as a period between the last days of growth phase and first day of regression phase. Data were divided according to pattern of follicular wave amount observed in 1 IOI (3 and 4-wave pattern group) and was tested by Independent-Sample $T$ Test. Repeatability ( $0-1$ value) was defined as proportion of total variance which was able to contribute to individual variance, and was calculated by formula: individual $\sigma^{2} /$ (individual $\sigma^{2}+\sigma^{2}$ error) (Burns et al. 2005). Component of variance for repeatability was estimated using ANOVA with single factor. Percentage of follicular ovulation was amount of ovulation in the left or right ovary divided by total follicular ovulation observed. Percentage of follicular wave occurrence in ovary was amount of follicular wave occurred in the right or left ovary divided by total follicular wave observed.
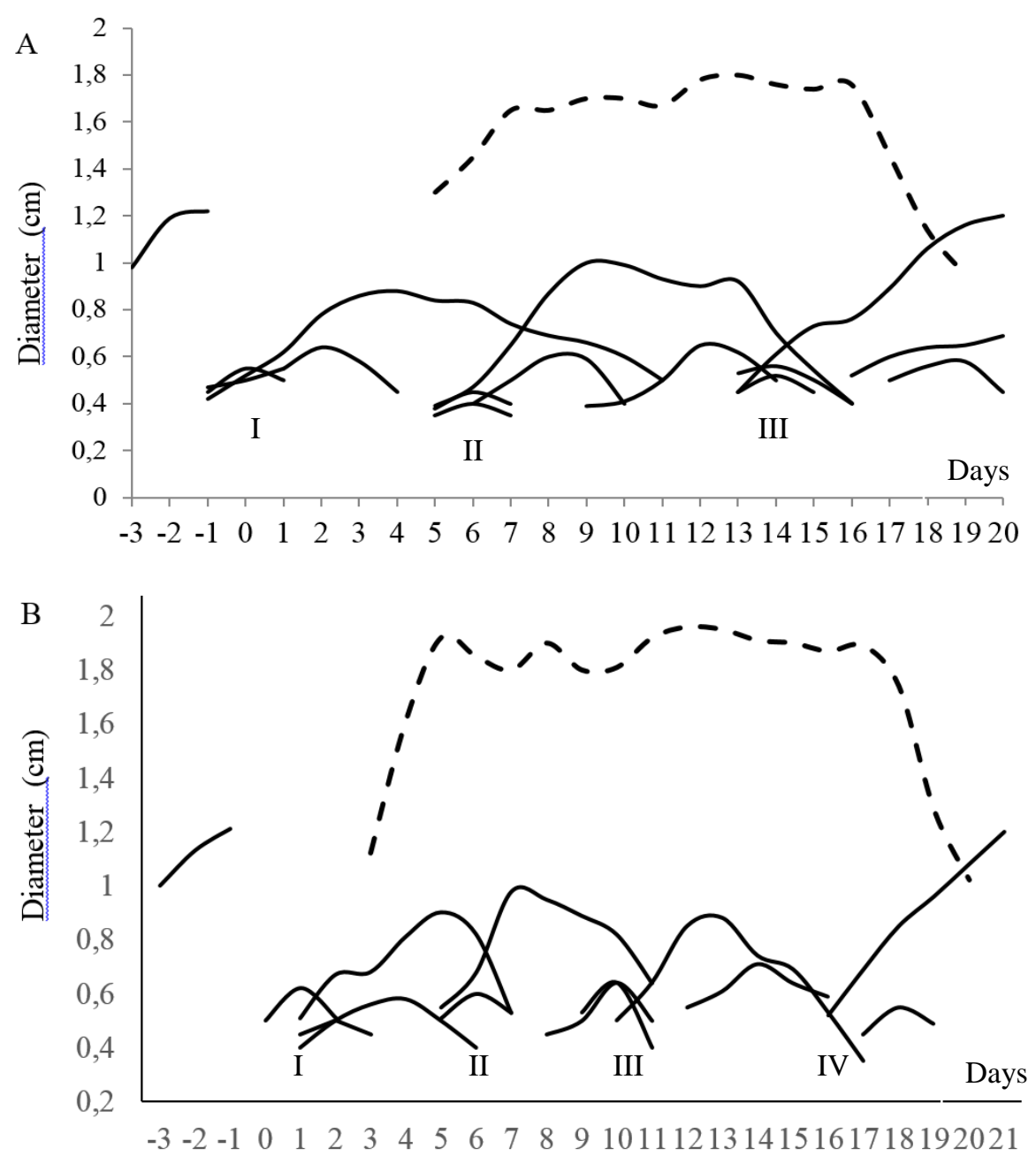

Figure 1. Growth pattern of follicular wave and CL in PO cattle with 3-follicular wave (A) and 4-follicular wave (B). Description: dotted line is CL growth pattern, solid line is follicular growth pattern. 


\section{RESULT AND DISCUSSION}

Based on daily observation of follicular dynamic, 6 cows $(66 \%)$ showed 3 -follicular wave pattern and the 3 $(33 \%)$ showed 4-follicular wave pattern (Figure 1) and there was no 2-wave pattern. Melia et al. (2014) reported that $6 \mathrm{PO}$ cattle showed 3-wave pattern. In other study, Viana et al. (2000) reported that there was only $1(6 \%)$ of 15 Gyr cattle (B. indicus) which had 2follicular wave pattern, the rest $60 \%$ and $26.7 \%$ had 3 and 4-follicular wave pattern, respectively.

Wave amount in 1 cycle was not affected by cattle breed (Adam et al. 2008), however Bó et al. (2003) reported that there was 3-wave pattern in poor nutrition and heat-stressed cattle. There was different in wave pattern proportion of heifer and cow in dairy cattle (Wolfenson et al. 2004). In other study, Adam et al. (2008) said that the most heifers $(65 \%)$ of Nellor cattle (B. indicus) showed 3-wave, while most of cows $(83 \%)$ showed 2-wave pattern. Satheshkumar et al. (2015) reported that 3-wave pattern emerged more frequently in the winter than the 2-wave pattern, and conversely in the summer.Follicular wave growth was initiated in day $-0.4 \pm 0.9$ and $1.4 \pm 1.1$ relative against ovulation in cattle with 3 and 4 follicular wave. The next follicular wave started to grow in day $8.1 \pm 1.5$ and $7.4 \pm 1.9$ for the 3 and 4 -wave pattern (Table 1). Three-wave pattern had the longest dominant duration (11.6+1.5 days) on the first wave and shorter on 4 -wave pattern $(10.0 \pm 2.9)$. This was in line with Adam et al. (2008) who said that there was a highly correlation between dominant duration with its wave amount pattern. Shorter dominant duration would increase the number of wave in 1 IOI. In other study, Jaiswal et al. (2009) said that dominant duration on the first wave in IOI might be used to predict wave amount pattern. Diameter of dominant follicle (DF) of each follicular wave in 3 and 4-wave pattern was not significantly different even diameter of dominant follicle tended to wane by increase of wave amount in 1 IOI (Table 1). Viana et al. (2000) said that decrease of diameter of dominant follicle and its dominant duration was associated with increase of wave amount in 1 estrous cycle. Bó et al. (2003) reported that the number of $B$. indicus $(16 \%)$ which had 4 follicular wave pattern was higher than $B$. taurus $(0 \%)$ and was allegedly due to a consequence of smaller diameter of dominant follicle and shorter dominant duration of $B$. indicus. High concentration estradiol suppressed LH impulse inducing synthesis of progesterone of luteal cells (Goodman et al. 1981; William et al. 1978), so that it was expected might affect function of luteal and its lifetime (Jaiswal et al. 2009).

However, on the third wave of 3-wave pattern which was an ovulatory follicle had significantly wider diameter than the third wave of 4-wave pattern (Table 1). As well it had wider diameter of ovulatory follicle than that non-ovulatory follicle in the same wave pattern. Progesterone produced by CL would suppress concentration of estradiol and growth rate of dominant follicle (Ramana et al. 2013; Junior et al. 2010), so that follicle growing during luteal phase had smaller diameter than ovulatory follicle growing during luteolysis.

One IOI cycle in this study tended to longer by increase of 3 and 4 wave pattern by $22 \pm 1.6$ and $22.8 \pm 2.9$ respectively (Table 2 ). It possibly related to size of follicular diameter in each wave pattern. Goff et al. (2004) said that estradiol in the first wave of IOI regulated time of oxytocin receptor emergence in endometrium that eventually managing prostaglandin production time to stimulate the luteolisis. There was a suspicion that size of follicular diameter on the first

Table 1. Characteristic per dominant follicular wave of PO cattle with 3 and 4 follicular wave in 1 IOI

\begin{tabular}{lcccc}
\hline \hline & & \multicolumn{3}{c}{ Follicular wave } \\
Observation & I & II & III & IV \\
\hline Onset follicle (day-): & & & & \\
3-wave & $-0.4 \pm 0.9$ & $8.1 \pm 1.5$ & $15 \pm 2.1$ & $16.2 \pm 3.2$ \\
4-wave & $1.4 \pm 1.1$ & $7.4 \pm 1.9$ & $12.2 \pm 1.5$ & - \\
Dominant duration (day) & & & & $6.6 \pm 0.9$ \\
3-wave & $11.6 \pm 1.5$ & $11 \pm 2.3$ & $6.8 \pm 1.3$ & - \\
4-wave & $10 \pm 2.9$ & $8.8 \pm 1.6$ & $7.7 \pm 1.5$ & $12.30 \pm 0.22$ \\
Diameter of DF (mm) & & & & $12.24 \pm 0.71^{\mathrm{a}^{*}}$ \\
3-wave & $10.05 \pm 0.43$ & $9.26 \pm 0.94$ & $9.1 \pm 1.44^{\mathrm{b}}$ & \\
4-wave & $9.42 \pm 0.44$ & $8.84 \pm 1.15$ & & \\
\hline
\end{tabular}

Different superscript in the same column and characteristic shows significant different in $\mathrm{P}<0.05$. *: Diameter of ovulatory follicle 
Table 2. Characteristic of dynamic of dominant follicle, subordinate follicle and corpus lutheum (CL) of PO cattle with 3 and 4 follicular waves

\begin{tabular}{lcc}
\hline \hline Characteristic & 3 -waves & 4 -waves \\
\hline Dominant Follicle & & 5 \\
The number of IOI & $22.0 \pm 1.6$ & $22.8 \pm 2.9$ \\
IOI length (day) & $0.87 \pm 0.23$ & $0.94 \pm 0.25$ \\
Growth rate (mm/day) & $3.7 \pm 2.0$ & $2.7 \pm 1.9$ \\
Static phase (day) & $0.83 \pm 0.21$ & $0.91 \pm 0.31$ \\
Atresia rate (mm/day) & $7.6 \pm 0.6$ & $7.4 \pm 1.1$ \\
Follicle growth to ovulation (day) & $12.24 \pm 0.71$ & $12.30 \pm 0.22$ \\
Diameter of ovulatory follicle (mm) & $6.25+0.37$ & $6.44+0.44$ \\
Diameter when deviation (mm) & $0.83 \pm 0.25$ & $0.72 \pm 0.33$ \\
Growth rate of subordinate follicle velocity (mm/day) & $18.94+0.47$ & $19.44+0.87$ \\
Diameter of CL on day-10 (mm) & & \\
\hline
\end{tabular}

wave of IOI affecting pattern of follicular wave amount formed (Adam et al. 2008, Jaiswal et al. 2009). However, Boer et al. (2011) said that mechanism of wave pattern forming was still unclear and was allegedly involving more complex follicular growth regulation.

In this study, growth rate of dominant follicle was not significantly different between 3 and 4-wave $(0.87+0.23$ and $0.94+0.25 \mathrm{~mm} /$ day, respectively) (Table 2). As well DF growth rate was not significantly different from SF until the follicular deviation. This was in line with Adam et al. (2008) who said that a group of follicle had the same growth rate at the beginning of growth until one follicle was selected to continuously grow to become a DF.

Initial of growth difference between the two biggest follicles was defined as follicular deviation (Ginther et al. 2003). In this study, deviation was occurred after the selected follicle reached diameter of $6.25+0.37$ and $6.44+0.44$ in 3 and 4 -wave respectively (Table 2). That was lower compared to follicular deviation in B. taurus breed by 8.5-9.0 mm (Ginther \& Hoffman et al. 2014, Sartori et al. 2001). This result was in line with Sartorelli et al. (2005) reporting that Nellor cattle (B. indicus) had smaller follicular diameter during deviation and ovulation than B. taurus. B. indicus breed had smaller follicle dominant than B. taurus, so that follicle dominant in $B$. indicus became smaller during follicular deviation (Bó et al. 2003).

When the DF depended on LH, there were only 2 possibilities: ovulation or regression (Lucy 2007). DF unexposed by LH surge would remind at a certain period (static phase) and then regressed (Valdez et al.
2005). During this period, DF would depend on growth factor supporting transition of G1 into $S$ phase of cellular cycle and prevented apoptosis in granulose cells (Quirk et al. 2004). At the certain time in static phase, DF would lose its dominant function even morphologically this follicle was the biggest size (Ireland et al. 2000). In this study, cows with 3-wave pattern had longer static phase by $3.7+1.9$ days than $4-$ wave pattern by $1.9+1.4$ days.

Ovulatory follicle of 3 and 4-wave had no significant difference diameter by $12.24+0.34$ and $12.30+0.23 \mathrm{~mm}$, respectively (Table 2 ). Growth length follicle into ovulation was also not different between 3 and 4-wave pattern (18.94+0.47 and $19.44+0.87 \mathrm{~mm}$, respectively) (Table 2). As well CL diameter in day-10 after ovulation was not significantly different between 3 and 4-wave pattern $(18.94+0.47$ and $19.44+0.87 \mathrm{~mm}$, respectively).

Wave amount pattern in this study had high repeatability value by 0.88 in the same individual (Table 3). It was in line with Jaiswal et al. (2009) who said that wave pattern had high repeatability value in crossed Hereford (B. taurus) cattle. Sichtar et al. (2010) reported almost equal proportion between individual experiencing a change or not in wave amount pattern in the same individual of dairy cattle.

The number of follicle growing in this study had high repeatability value by 0.91 in the same individual. Another studies also reported that the number of follicle recruited into one wave had high repeatability value in the same individual, but was varied in the different individual (Santos et al. 2014; Ireland et al. 2007; David et al. 2005). Singh et al. (2004) reported that the high 
Imron et al. Follicular dynamic and repeatability of follicular wave development in Peranakan Ongole (PO) cattle

Table 3. Value of characteristics of follicular dynamic observed in PO cattle

\begin{tabular}{lc}
\hline \hline Observation & Value \\
\hline Repeatability of (3 and 4) follicular wave pattern respectively in 2 IOI in the same individual & 0.88 \\
Repeatability of follicle amount growing in the same individual & 0.91 \\
Average follicle amount at the beginning of follicular wave growth & $27.3 \pm 9.4$ \\
Percentage of ovulation in the right and left ovary & $72 \%$ and $28 \%$ \\
Percentage of follicular wave in the right and left ovary & $52 \%$ and $48 \%$ \\
Repeatability of follicular wave in the right and left ovary & 0.14 and 0.10 \\
\hline
\end{tabular}

number of antral follicle had a positive correlation to gonadotropin treatment during superovulation and produced more oocyte and transfer-feasible embryo. So that, characteristic of repeatability of high number of PO cattle might be used as parameter of donor selection to increase effectiveness of superovulation. In this study, ovulation in right ovary was higher $(72 \%)$ than in the left (Table 3). It was in line with Vasenna et al. (2003) and Nation et al. (1999) who reported that ovulation more often occurred in the right ovary than in the left. However, Purwantara et al. (2006) and Ginther et al. (1989) reported balance ovulation in the right and left ovary. In other hand, percentage of the number of follicular wave formed between the right and left ovary was practically balance (52\% and $48 \%$ respectively) showing that actually, right and left ovary had the same activity in folliculogenesis.

Repeatability of follicular wave emergence in the same ovary was too low both in the right and left ovary (0.14 and 0.10 , respectively) showing a process of randomly follicular wave forming in the right and left ovary. This was different from Vasenna et al. (2003) reporting that activity of the right ovary was higher than the left. It was just 1 from a pair of follicle would be selected to be DF both in ipsilateral or contralateral position against the biggest subordinate follicle.

This study provided basic data of follicular dynamic and its repeatability in PO cattle based on USG observation. A better understanding of follicular dynamic was very useful in its utilization for purposes with more specific reproduction management such as in superovulation program. Some field studies had been conducted to implement superovulation program to other native cattle (Bali, Madura, and Aceh cattle) with standard superovulation protocol as applied in Bos taurus breed. However, until now response of superovulation produced was not as expectation. This indicated the urgent of understanding of follicular dynamic characteristics of each native cattle breed to be used as a basic data in implementation reference of reproduction technology, especially that superovulation program.

\section{CONCLUSION}

This study showed that characteristic of follicular dynamic of PO cattle was dominated by 3-waves pattern in 1 estrous cycle. Repeatability of wave pattern and follicle number had high value in the same individual. Those characteristics might be used for reproduction management of donor cattle to increase superovulation effectiveness based on individual information.

\section{REFERENCES}

Adams GP. 1999. Comparative patterns of follicle development and selection in ruminants. J Reprod Fertil. 54:17-32.

Adams GP, Jaiswal R, Singh J Malhi P. 2008. Progress in understanding ovarian follicular dynamics in cattle. Theriogenology. 69:72-80.

[BET] Balai Embrio Ternak. 2012. Laporan tahunan: Evaluasi produksi dan transfer embrio. Bogor (Indones): Balai Embrio Ternak. hlm. 31-36.

Bleach ECL, Glencross RG, Knight PG. 2004. Association between ovarian follicle development and pregnancy rates in dairy cows undergoing spontaneous oestrous cycles. Reproduction. 127:621-629.

Boer HMT, Röblitz L, Stötzel C, Veerkamp RV, Kemp B, Woelders H. 2011. Mechanisms regulating follicular wave patterns in the bovine estrous cycle investigated with a mathematical model. J Dairy Sci. 94:5987-6000.

Bó GA, Baruselli PS, Mart MF. 2003. Pattern and manipulation of follicular development in Bos indicus cattle. Anim Reprod Sci. 78:307-326.

Beg MA, Bergfelt DR, Kot K, Ginther OJ. 2002. Follicle selection in cattle: dynamics of follicular fluid factors during development of follicle dominance. Biol Reprod. 66:120-126.

Burns DS, Jimenez-Krassel FJ, Ireland JJ. 2005. Numbers of antral follicles during follicular waves in cattle: evidence for high variation among animals, very high repeatability in individuals, and an inverse association 
with serum follicle-stimulating hormone concentrations. Biol Reprod. 73:54-62.

David SB, Jimenez-Krassel F, Ireland JLH, Knight PG, James J. 2005. Numbers of antral follicles during follicular waves in cattle: evidence for high variation among animals, very high repeatability in individuals, and an inverse association with serum follicle-stimulating hormone concentrations. Biol Reprod. 73:54-62.

Ereno RL, Pupulim AG, Loureiro B, Favoreto MG, Castilho ACS, Buratini J, Barros CM. 2013. The effect of nutrition onovarian follicle population and plasma antiMullerian hormone con-centration in Aberdeen Angus heifers. Reprod Fertil Dev. 25:236.

Fair T, Hulshof SCJ, Hyttel P, Greve T, Boland M. 1997. Oocyte ultrastructure in bovine primordial to early tertiary follicles. Anat Embryo. 195:327-336.

Fortune JE, Cushman RA, Wahl CM, Kito S. 2000. The primordial to primary follicle transition. Mol Cell Endocrinol. 163:53-60.

Ginther OJ, Knopf L, Kastelic JP. 1989. Temporal associations among ovarian events in cattle during oestrous cycles with two and three follicular waves. J Reprod Fertil. 87:223-230.

Ginther OJ, Kot K, Kulick LJ, Wiltbank MC. 1997. Emergence and deviation of follicles during the development of follicular waves in cattle. Theriogenology. 48:75-87.

Ginther OJ, Hoffman MM. 2014. Intraovarian effect of dominant follicle and corpus luteum on number of follicles during a follicular wave in heifers. Theriogenology. 82:169-175.

Ginther OJ, Beg MA, Donadeu FX, Bergfelt DR. 2003 Mechanism of follicle deviation in monovular farm species. Anim Reprod Sci. 78:239-257.

Goodman RL, Bittman EL, Foster DL, Karsch FJ. 1981. The endocrine basis for the synergistic suppression of luteinizing hormone by estradiol and progesterone. Endocrinology. 109:1414-1417.

Goff AK. 2004. Steroid hormone regulation of prostaglandin secretion in the ruminant endometrium during the estrous cycle. Biol Reprod. 71:11-16.

Ireland JJ, Mihm M, Austin E, Diskin MG, Roche JF. 2000. Historical perspective of turnover of dominant follicles during the bovine estrous cycle: key concepts, studies, advancements, and terms. J Dairy Sci. 83:1648-1658.

Ireland JJ, Ward F, Jimenez-Krassel F, Ireland JLH, Smith GW, Lonergan P, Evans ACO. 2007. Follicle numbers are highly repeatable within individual animals but are inversely correlated with FSH concentrations and the proportion of good-quality embryos after ovarian stimulation in cattle. Human Reproduction. 22:16871695 .

Jaiswal RS, Singh J, Marshal L, Adam GP. 2009. Repeatability of 2-wave and 3-wave patterns of ovarian folicular development during the bovine estous cycle. Theriogenology. 71:81-90.

Junior CI, Sa-Filho OG, Perez RFG, Aono FHS, Day ML, Vasconcelos JLM. 2010. Reproductive Performance of prepubertal Bos indicus herifer after progesteron-based treatments. Theriogenology. 74:903-911.

Kanitz W. 2003. Follicular dynamic and ovulation in cattle: A review. Arch Tierz. 46:187-198.

Melia J, Amrozi, Tumbelaka LI. 2014. Dinamika ovarium sapi endometritis yang diterapi dengan gentamicine, flumequine dan analog prostaglandin $\mathrm{F} 2$ alpha $\left(\mathrm{PGF}_{2} \alpha\right)$ secara intra uterus. J Kedokteran Hewan. 8:111-115.

Melvin EJ, Lindsey BR, Quintal-franco J, Zanella, Fike KE, Van Tassell CP, Kinder JE. 1999. Circulating concentrations of estradiol, luteinizing hormone, and follicle-stimulating hormone during waves of ovarian follicular development in prepubertal cattle. Biol Reprod. 60:405-412.

Mihm M, Baker PJ, Ireland JLH, Smith GW, Coussens PM, Evans ACO, Ireland JJ. 2006. Molecular evidence that growth of dominant follicles involves a reduction in follicle stimulating hormone dependence and an increase in luteinizing hormone dependence in cattle. Biol Reprod. 74:1051-1059.

Monniaux D, Barbey S, Rico C, Fabre S, Gallard Y, Larroque H. 2010. Anti-Müllerian hormone: a predictive marker of embryo productionin cattle?. Reprod Fertil Dev. 22:1083-1091.

Mossa F, Walsh SW, Butler ST, Berry DP, Carter F, Lonergan P, Smith GW, Ireland JJ, Evans ACO. 2012. Low numbers of ovar-ian follicles $\geq 3 \mathrm{~mm}$ in diameter are associated with low fertility indairy cows. J Dairy Sci. 95:2355-2361.

Murphy MG, Boland MP, Roche JF. 1990. Pattern of follicular growth and resumption of ovarian activity in post-partum beef suckler cows. J Reprod Fertil. 90:523533.

Nation DP, Burke CR, Rhodes FM, Macmillan KL. 1999. The inter-ovarian distribution of dominant follicles is influenced by the location of the corpus luteum of pregnancy. Anim Reprod Sci. 56:169-176.

Lucy MC. 2007. The bovine dominant ovarian follicle. J Anim Sci. 85:89-99.

Lussier JG, Matton P, Dufour JJ. 1987. Growth rates of follicles in the ovary of the cow. J Reprod Fertil. 81:301-307.

Parrott JA, Skinner MK. 2000. Kit ligand actions on ovarian stromal cells: Effects on theca cell recruitment and steroid production. Mol Reprod Dev. 55:55-64.

Purwantara B, Hoier R, Schmidt M, Greve T. 2006. Preovulatori changes and ovulation in cattle undergoing spontaneous or clopprostenol-induced luteolyis. Biotropia. 13:75-84.

Quirk SM, Cowan RG, Harman RM, Hu CL, Porter DA. 2004. Ovarian follicular growth and atresia: The 
Imron et al. Follicular dynamic and repeatability of follicular wave development in Peranakan Ongole (PO) cattle

relationship between cell proliferation and survival. J Anim Sci. 82:40-52.

Ramana KV, Rao KV, Supriya K, Rajanna N. 2013. Postpartum ovarian follicular dynamics and estrus activity in lactating Ongole cows. J Res Angrau. 41:5155.

Roche JF, Austin EJ. Ryan M, O'rourke M, Mihm M, Diskin MG. 1999. Regulation of follicular waves to maximize fertility in cattle. J Reprod Fertil. 54:61-71.

Santos KC, Santos GMG, Siloto LS, Morotti F, Marcantonio TN, Seneda MM, 2014. Comparison of antral and preantral ovar-ian follicle populations between Bos indicus and Bos taurus cows with high or low antral follicles counts. Reprod Dom Anim. 49:48-51.

Sartori R, Fricke PM, Ferreira JCP, Ginther OJ, Wiltbank MC. 2001. Follicular deviation and acquisition of ovulatory capacity in bovine follicles. Biol Reprod. 65:1403-1409.

Sartorelli ES, Carvalho LM, Bergfelt DR, Ginther OJ, Barros CM. 2005. Morphological characterization of follicle deviation in Nelore (Bos indicus) heifers and cows. Theriogenology. 63:2382-2394.

Satheshkumar S, Brindha K, Roya A, Devanathan TG, Kathiresan D, Kumanan K. 2015. Natural influence of season on follicular, luteal, and endocrinological turnover in Indian crossbred cows. Theriogenology. 84:19-23.

Sichtar J, Tolman R, Rajmon R, Klabanová P, Berka P, Volek J. 2010. A comparison of the follicular dynamics in heifers of the Czech Fleckvieh and Holstein breeds. Czech J Anim Sci. 55:234-242.
Silva-Santos KC, Santos GMG, Siloto LS, Morotti F, Marcantonio TN, Seneda MM. 2014. Comparison of antral and preantral ovarian follicle populations between Bos indicus and Bos indicus-taurus cows with high or low antral follicles counts. Reprod Dom Anim. 49:4851 .

Siddiqui MAR, Ginther OJ. 2014. Switching of largest follicle from dominant to subordinate status when follicle and $\mathrm{CL}$ are in same ovary in heifers. Theriogenology. 82:259-265.

Taylor C, Rajamahendran R. 1991. Follicular dynamics, corpus luteum growth and regression in lactating dairy cattle. Canadian J Anim Sci. 71:61-68.

Valdez KE, Cuneo SP, Turzillo AM. 2005. Regulation of apoptosis in the atresia of dominant bovine follicles of the first follicular wave following ovulation. Reproduction. 130:71-81.

Viana JHM, Ademir MF, Wanderlei FS, Almeida LS, Camargo. 2000. Follicular dynamics in zebu cattle. Pesq Agropec Bras. 35:2501-2509.

Williams MT, Marsh JM. 1978. Estradiol inhibition of luteinizing hormone-stimulated progesterone synthesis on isolated bovine luteal cells. Endo. 103:1611-1618.

Wolfenson D, Inbar G, Roth Z, Kaim M, Bloch A, Braw R. 2004. Follicular dynamics and concentrations of steroids and gonadotropins in lactating cows and nulliparous heifers. Theriogenology. 62:1042-1055.

Vasenna R, Mapletoft RJ, Allodi S, Singh J, Adams GP. 2003. Morphology and developmental competence of bovine oocytes relative to follicular status. Theriogenology. 60:923-932. 